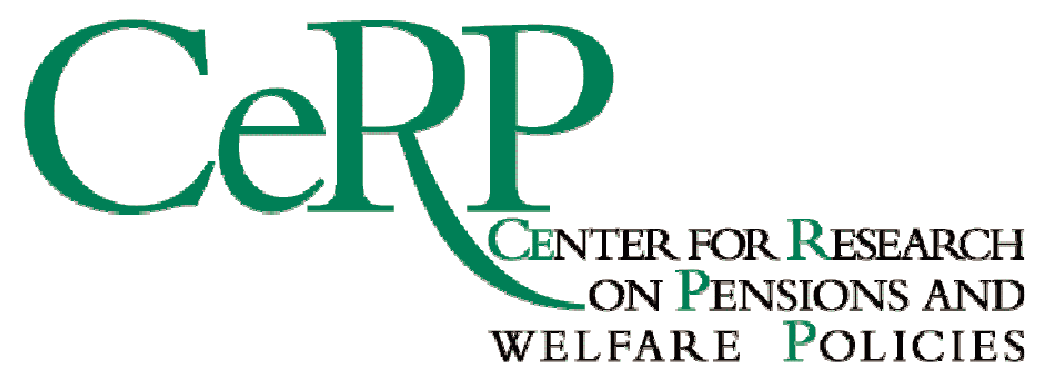

Working Paper 120/11

\title{
AGE BEFORE BEAUTY? PRODUCTIVITY AND WORK VS. SENIORITY AND EARLY RETIREMENT
}

Giovanni Mastrobuoni

Filippo Taddei 


\title{
Age Before Beauty? Productivity and Work vs. Seniority and Early Retirement *
}

\author{
Giovanni Mastrobuoni $^{\dagger} \quad$ Filippo Taddei ${ }^{\ddagger}$ \\ May 2011
}

\begin{abstract}
We show how the age profile of earnings, retirement rules and retirement behavior are tightly linked through the general equilibrium of the economy. Generous Social Security benefits financed by large Social Security taxes discourage human capital accumulation. In Social Security systems where Social Security benefits prioritize redistribution less productive workers with lower levels of human capital tend to retire earlier. These outflows of workers from the labor force tend to generate wage profiles that are monotonically increasing over age and labor markets that display larger seniority premia.

This paper theoretically rationalizes the links between retirement rules and the wage structures over the life cycle and uses data on European countries to show how social security taxes, the age profile of earnings, and retirement behavior are related.
\end{abstract}

Keywords: Social Security tax, early retirement, age profile of earnings, human capital, seniority premium

JEL classification codes: H53; H55; D72

${ }^{*}$ We thank Elsa Fornero and Flavia Coda Moscarola for their help, and participants at the ALPOP conference for their comments. We are grateful to Regione Piemonte and NETSPAR for their financial support.

${ }^{\dagger}$ Collegio Carlo Alberto, CeRP and Netspar, , Via Real Collegio 30, Moncalieri (TO), Italy, E-mail: giovanni.mastrobuoni@carloalberto.org.

${ }_{\ddagger}^{\ddagger}$ Collegio Carlo Alberto and CeRP, Via Real Collegio 30, Moncalieri (TO), Italy. E-mail: filippo.taddei@carloalberto.org 


\section{Introduction}

Social Security systems are likely to come under severe financial stress in the near future, mainly because of the progressive aging of populations. By 2050, the ratio between the elderly population (aged 65 and above) and the working age population (aged 15 to 64) is expected to double with respect to its 2010 level in almost all European countries (Visco, 2005). The ratio between retirees and people of working age is going to increase even more dramatically (Galasso, 2008). Developed economies, starting with China, will soon face similar generational tensions. Even though the financial distress of Social Security Systems (SSSs) in advanced economies resembles a ticking bomb, the pace of reforms does not appear to be sufficiently fast. The explanation for this delay is probably linked to the shift in the demographic structure toward old age: it is politically easier to shift the burden of the reforms to the younger generations. We argue that the reforms need to be accelerated to avoid additional increases in Social Security taxes. As we show in this paper, these increases are likely to have major effects by leading to changes in the level of human capital and in the age profile of wages. We not only rationalize these features in the general equilibrium of the economy, but also show they are related to each other within European countries.

Academics and policy-makers often overlook that Social Security rules are interlinked with the age profile of productivity and earnings over workers' careers. We show in this paper that these two characteristics of the economy are part of the same general equilibrium. In fact, the age at which an agent chooses to retire depends on his stock of human capital in so far human capital determines their productivity in the labor market. The reason is simple: the higher is human capital, the higher is labor income, and so the smaller is the incentive to retire. Since, in general, people differ in their ability to acquire and maintain human capital, less productive individuals retire in disproportionate number from the labor force. But this observation is not enough to rationalize the starkly different behavior in retirement decision across workers in different European economies. The crucial observation we make here gives a central role to the level of 
social security taxation. In the empirical evidence we present regarding European countries, we highlight that the average retirement age tend to be lower in countries where social security taxes are higher and the labor market, including the private sector, rewards relatively more seniority. We propose a general equilibrium perspective to systematically rationalize these features.

The intuition is the following. In economies where the social security tax is high, the private benefit of human capital accumulation are reduced while the Social Security benefits tend to be large and the early retirement age tends to be low. Then only the most productive individuals find it convenient to remain workers because their high human capital commands high wages. The selection among workers is reflected in the average wage observed among more senior workers and in the aggregate the labor market displays a more pronounced seniority premium. As a consequence of high social security taxation and the resulting low investment in human capital, the aggregate effective human capital is reduced, labor income stays stagnant and, on average, individuals retire earlier. While the age profile of wages is increasing for economies with high social security tax, this is not the case, by a specular reasoning, when social security taxes are low. In these economies even low productivity individuals find it convenient to accumulate more human capital and remain active in the labor market for longer periods. In this latter group of economies the average wage by age class follows the dynamic of individual human capital: it first increases and then it decreases in the second half of the working career. The age profile of wages takes a more hump-shaped structure and the seniority premium falls.

This study has two main contributions, both a theoretical and an empirical one, relating Social Security rules and the age profile of wages. First, while we are certainly not the first to observe that Social Security in general and the level of social security taxation in particular affects the accumulation of human capital and retirement decision, especially among the least productive individuals, Conde-Ruiz et al., 2005, Conde-Ruiz and Galasso, 2003, 2004), this is to our knowledge the first paper to link it the shape of the age profile of earnings to SSSs and to highlight how these profiles differ among European countries in terms of the seniority premium. 
Differently from the seminal contribution of Lazear (1979), we show how these differences do not necessarily reflect discrepancies between the wage and individual productivity. Establishing this link is not just an intellectual curiosity, but it is an important observation for policy. As SSSs enter additional distress because of the aging population, policy reforms point in the direction of increasing the level of social security taxation, possibly in alternative to an retirement age increase. As we point out in this paper, policymakers should be particularly wary of taking this view because raising social security taxation not only decreases human capital, but it also has the effect of making individuals, especially but not only the low productivity ones, less eager to remain in the labor force. We also provide an empirically valid measure of the severity of this phenomenon: the seniority premium observed in the labor market.

The first part of the paper develops a general equilibrium model to help to systematically tie together the age profile of earnings and Social Security. The second part provides crosscountry evidence supporting the view that there is a robust empirical relationship, within European countries, between high Social Security taxes, low investment in human capital, labor markets that reward more seniority, early retirement and low labor market participation at old age.

\section{The Economy}

Consider an economy inhabited by overlapping generations of individuals living for $T$ periods, all with size one. We use $J_{t}$ to denote the set of individuals born at time $t$, i.e. generation $t$. Time starts at $t=0$ and then goes on forever. Individuals $J_{t}$ leave the economy at the end of period $t+T$.

Each individual acquires human capital that depreciates over time in order to foster his productivity and income. We label the amount of human capital by individual $j$ of generation $t$ at time $i$ by $h_{t}^{i}(j), i \in\{t, \ldots, t+T\}$. Wherever ambiguous, we will adopt the notational convention that,




which the variable refers. Human capital is valuable because it increases individual's productivity, and thus the effective wage while working. Every individual $j \in J_{t}$ maximizes the sum of her lifetime income, net of the cost of human capital accumulation:

$$
U_{t}(j)=\sum_{i=t}^{t+T} y\left(h_{t}^{i}(j)\right)-C^{j}\left(h_{t}^{i}(j)\right)
$$

where

$$
\begin{gathered}
C^{j}\left(h_{t}(j)\right)=\sum_{i=t}^{t+T} c^{j}\left(x_{t}^{i}(j)\right), \\
h_{t}^{i}(j)=\left\{\begin{array}{c}
x_{t}^{i}(j) \text { if } i=t \\
h_{t}^{i-1}(j)(1-\delta)+x_{t}^{i}(j) \text { if } i>t
\end{array},\right. \\
\frac{d c^{j}\left(x_{t}^{i}(j)\right)}{d x_{t}^{i}(j)}>0, \frac{d^{2} c^{j}\left(x_{t}^{i}(j)\right)}{d^{2} x_{t}^{i}(j)}<0 .
\end{gathered}
$$

$y($.$) is per period income, C^{j}($.$) is the total cost of the sequence of human capital accumulated over$ individual $j$ 's life, i.e. $h_{t}(j)=\left[h_{t}^{i}(j)\right]_{i \in\{t, \ldots, t+T\}}$. The strictly convex function $C^{j}($.$) is a reduced$ form expression that captures the individual specific cost of education, the opportunity cost of learning on the job and, in general, all the resources required to build up and maintain the vector of human capital $h_{t}(j)$ by individual $j$. It should be noted that, in our setup, the cost to maintain the level of human capital $h_{t}^{i}(j)$ of individual $j$ in period $i$ depends only on the amount added by the individual in that specific period, i.e. $x_{t}^{i}(j)$.

The crucial feature of this economy is that individuals differ in their ability to acquire skills and human capital and this difference is persistent over the life cycle. Formally, this heterogeneity is captured by the function $c^{j}($.$) that we assume to be increasing in the label j$, for any given level of human capital $h_{t}^{i}$. This means that if we compare individual $\bar{j}>\underline{j}$, then the marginal cost of human capital is higher for $\bar{j}$ :

$$
\frac{d c^{\bar{j}}(x)}{d x}>\frac{d c^{j}-(x)}{d x}, \forall x
$$


The second crucial feature of our setup is that agents do not only invest in human capital that is useful to work, but they also decide when they exit the labor force and retire, conditional on the institutional constraints that may exist. Once an individual stops working, she retires to collect from the SSS a (possibly time variant) benefit. Formally, $r_{t}^{j}$ is the label we apply on the period in which individual $j$ of generation $t$ exits the labor force and retires. Therefore an individual $j$ with the level of human capital $h_{t}^{i}(j)$ in period $i$ obtains an income at time $\tilde{t}$ equal to:

$$
y^{\widetilde{t}}\left(h_{t}^{i}(j)\right)=\left\{\begin{aligned}
w_{\tilde{t}}\left(h_{t}^{i}(j)\right) & =w_{\tilde{t}}(1-\tau) \cdot f\left[h_{t}^{i}\right] \text { if } j \text { works, i.e. } \tilde{t} \in\left\{t, \ldots, r_{t}^{j}-1\right\} \\
& b_{\tilde{t}}(j) \text { if } j \text { is retired, i.e. } \tilde{t} \in\left\{r_{t}^{j}, \ldots, t+T\right\}
\end{aligned}\right.
$$

where $f[$.$] is an increasing, strictly concave and differentiable function that translates individual$ human capital into actual efficiency units useful for production, $w_{\tilde{t}}$ is the time dependent unitary wage for each efficiency unit, $\tau$ is the social security tax and $b_{\hat{t}}(j)$ is the Social Security benefit an individual receives after she leaves the labor force. The concavity of $f$ [.] is meant to capture the realistic feature that, although productivity is increasing in the level of individual human capital, it is so at a decreasing rate.

For the sake of simplicity we will abstract from social security debt and we will assume throughout the analysis that the SSS accounts are always balanced 11 Therefore, we have:

$$
w_{t} \tau \cdot \sum_{r_{k}^{j}-1 \geq t}\left(\int_{0}^{J_{k}} f\left[h_{k}^{t}(j)\right] d j\right)=\sum_{r_{k}^{j}<t}\left(\int_{0}^{J_{k}} b_{t}(j) d j\right), \forall t .
$$

Condition (4) implies that the Social Security benefit $b_{t}(j)$ is determined in equilibrium by the level of taxation $\tau$ and the average length of individuals' working career before retiring, i.e. $\left(r_{t}^{j}-1-t\right)$. In principles $b_{t}(j)$ can be time variant and individual $j$ specific.

We will abstract from the political economy process leading to the specific level of the social

\footnotetext{
${ }^{1}$ This assumption is not necessary to deliver the results of our analysis. Even if social security debt were to be issued, we just need the redistribution that is financed through debt not to be too large.
} 
security $\operatorname{tax} \tau$ observed in reality. Taking $\tau$ as exogenous, we concentrate instead on how human capital accumulation, and thus the age profile of earnings, is determined by the level of social security taxation. In order to do so we have to define how the unitary wage for human capital is determined. We assume that output is a function of aggregate human capital:

$$
Y_{t}=A_{t} H_{t}
$$

where $H_{t}$ is the aggregate measure of efficiency units in the economy and is equal to

$$
H_{t}=\sum_{r_{k}^{j}-1 \geq t}\left(\int_{0}^{J_{k}} f[.] d j\right)
$$

$A_{t}$ is a (possibly time variant and stochastic) index of the productivity of human capital. The production function (5) and condition (6) jointly determine the reward for a unit of human capital when the wage is set competitively. Therefore we have that, at any point, the wage tracks the efficiency of the production function:

$$
w_{t}=A_{t}
$$

\subsection{The Definition of the Competitive Equilibrium}

In every period $t$, the competitive equilibrium is defined by human capital vectors $h_{k}(j), \forall j \in J_{k}$, $k \in\{t-T, \ldots, t\}$, retirement ages $r_{t}^{j}, \forall j \in J_{t}$, wage $w_{t}$ and pension benefit $b_{t}(j)$ such that:

1. individuals optimize

$$
h_{k}(j) \epsilon \arg \max U_{k}^{j}, k \in\{t-T, \ldots, t\},
$$

2. the output market clears

$$
w_{t} \cdot H_{t}=w_{t} \cdot \sum_{r_{k}^{j}-1 \geq t}\left(\int_{0}^{J_{k}} h_{k}^{t}(j) d j\right)=Y_{t}
$$


3. the SSS keeps a balanced budget so that equation (4) is satisfied.

\subsection{The Life Cycle of Human Capital, the Age Profile of Earnings and Retirement}

For the sake of exposition we are now going to make two simplifying assumption. In particular we will assume that productivity is constant over time, i.e. $A_{t}=A \forall t$, and that the population is stationary, $J_{t}=1 \forall t$. These assumptions are not necessary for our results to go through but they allow the determination of the equilibrium of the economy avoiding numerical simulations. Specifically, under our simplifying assumptions, we can drop the subscript $t$ under the wage $w$ and the $j$-specific human capital level in period $i, h^{i}(j)$.

Moreover, we want to capture, though in a stylized fashion, the fundamental features of the SSSs present within European countries. First, SSSs typically display a highly progressive structure ensuring that the most productive individuals implicitly subsidize the least productive ones through the Social Security benefit. Second, once individuals retire, the SSS is set to guarantee that the Social Security benefit is (weakly) non-decreasing over time in real terms. Finally, SSSs do not allow workers to retire whenever they choose but they impose some minimal retirement age defined by the number of years an individual has been working, a minimum retirement age or a combination of the two conditions. Keeping these features in mind, we formally define a SSS:

Definition A SSS is defined by a social security tax $\tau$ and a Social Security benefit function b(.) satisfying the following features:

1. the Social Security benefit is equal for all individuals, i.e. $b_{t}(j)=b_{t}, \forall j$;

2. the Social Security benefit is constant in real terms across time, i.e. $b_{t}=b, \forall t$; 
3. the period in which individual $j$ of generation t may choose to retire must satisfy a minimum age requirement, i.e. $\left(r_{t}^{j}-t\right) \geq \kappa, \kappa \in\{1, \ldots, T\}$ and $\forall t$.

While conditions 2 and 3 in the definition of SSS introduced above are straightforward and characterize most of SSSs, condition 1 deserves a quick comment. In general the Social Security benefit an individual receives is positively correlated with personal income, summarized by the sufficient statistics $j$ in our setup. For the sake of simplicity, we abstract from this feature and stress the fact that SSSs heavily subsidize individuals with lower earnings. Therefore, in our formal argument we take the shortcut of assuming that every retired worker receives the same Social Security benefit. Although this is not precisely correct, it is consistent with the redistribution that SSSs put in place and it provides an approximation that will be useful later.

We are now ready to study the condition that the generic agent $j$ of generation $t$ ponders when deciding whether to retire or remain in the labor force. In order to study this problem, it is convenient to begin from the end of the lifetime and then work backward. In a given period $i \geq \kappa$ an agent remains in the labor force until her labor income, net of the maintenance cost of human capital, weakly exceeds the Social Security benefit:

$$
w\left(h^{i}(j)\right) \cdot(1-\tau)-c^{j}\left(x^{i}(j)\right)=A \cdot f\left[h^{i-1}(j)(1-\delta)+x^{i}(j)\right] \cdot(1-\tau)-c^{j}\left(x^{i}(j)\right) \leq b(j)=b
$$

Simple derivation of condition $\left.(7)\right|^{2}$ with respect to the increment in human capital $x^{i}(j)$ suffices to show that in any period $i$ there will be an individual $j^{i}$ that, even if she invested the optimal amount in human capital accumulation, would weakly prefer to retire and receive the Social Security benefit:

$$
j^{i}=\min _{j \in J}:\left[x^{i}(j): \sum_{z=i}^{T}(1-\delta)^{z-i} \frac{\partial f\left[h^{z}(j)\right]}{\partial x^{z}(j)}=c^{j}\left(x^{i}(j)\right)\right] \wedge\left[w\left(h^{i}(j)\right) \cdot(1-\tau)-c^{j}\left(x^{i}(j)\right) \leq b\right]
$$

\footnotetext{
${ }^{2}$ Notice that we have omitted the time subscript $t$ since, under the stated assumptions, all generations face an identical problem.
} 
It is worthwhile to observe that any individual indexed by $j>j^{i}$ would also choose to retire in period $i$ because it is also more costly for him to accumulate human capital than for individual $j^{i}$. Therefore we can also define, for a generic individual $j$, the beginning of retirement by the first period $r^{j}$ satisfying the minimum age requirement and condition (7):

$$
r^{j}=\min _{r^{j} \geq \kappa, \kappa \in\{1, \ldots, T\}} i \in\{1, \ldots, T\}: w\left(h^{i}(j)\right) \cdot(1-\tau)-c^{j}\left(x^{i}(j)\right) \leq b(j)=b
$$

For a given social security $\operatorname{tax} \tau$ and sequence of Social Security benefit $b$, maximization of utility (1) with respect to the human capital $x_{t}^{i}(j)$ that individual $j$ of generation $t$ accumulates in period $i$ satisfies the following:

$$
\begin{gathered}
\max _{h_{t}(j)=\left[h_{t}^{i}(j)\right]_{i \in\{t, \ldots, t+T\}}} U(j) \\
\Leftrightarrow \\
A \cdot(1-\tau) \cdot \sum_{z=i}^{r_{t}^{j}-1}(1-\delta)^{(z-i)} \frac{\partial f\left[h^{z}(j)\right]}{\partial x^{z}(j)}=\frac{\partial\left[c^{j}\left(x_{t}^{i}(j)\right)\right]}{\partial x_{t}^{i}(j)}
\end{gathered}
$$

The condition 100 has an intuitive interpretation. First, it states that the benefit of investing in the build-up of human capital depends on the future wages this investment secures, $\sum_{z=i}^{r_{t}^{j}-1}(1-$ $\delta)^{(z-i)} \frac{\partial f\left[h^{z}(j)\right]}{\partial x^{z}(j)}$, net of taxation $(\tau)$. Second, in every period, agents build up additional human capital until its marginal cost, $\frac{\partial\left[c^{j}\left(x_{t}^{i}(j)\right)\right]}{\partial x_{t}^{i}(j)}$, equates its marginal benefit. By joining 10 and the assumption that agents have heterogenous ability to accumulate human capital - condition (3) it is immediate to observe that the level of human capital investment falls with the individual's ability to accumulate it, i.e. $c^{j}($.$) . Formally:$

$$
x^{i}\left(j^{\prime}\right)<x^{i}(j) \text { if } j^{\prime}>j
$$

Most interestingly from our point of view, we can now study how the level of human capital changes over the life cycle of a generic individual. Given the level of the social security tax $\tau$, 
condition (10) shows that the largest investment in human capital takes place at the beginning of life. The reason is straightforward: the marginal benefit $-\sum_{z=i}^{r_{t}^{j}-1}(1-\delta)^{(z-i)} \frac{\partial f\left[h^{z}(j)\right]}{\partial x^{z}(j)}$ is the highest and the marginal cost $-\frac{\partial\left[c^{j}\left(x_{t}^{i}(j)\right)\right]}{\partial x_{t}^{i}(j)}$ - is the same. As individuals age the marginal cost remains the same, while the marginal benefit falls progressively as the same human capital investment now commands lower future wages because of the reduced working horizon and the concavity of human capital effectiveness - $f[$.$] . Therefore, the investment per period in human capital decreases as$ individuals approach retirement age, i.e. $i \rightarrow r^{j}$. But since, as setup in condition (2), human capital depreciates over time at the constant rate $\delta$, it is straightforward to conclude that the stock of human capital, $h^{i}(j)$, must initially increase over the first part of the working career, peak around its middle and fall as retirement becomes closer and closer. Eventually the effect of depreciation dominates the effect of additional investment in human capital and so the stock of human capital $h_{t}^{i}(j)$ falls as retirement approaches, i.e. $i \rightarrow r_{t}^{j}$. Therefore, while at the beginning of the working career the additional investment in human capital is large and more than enough to compensate for the fall in the stock of human capital due to depreciation, this ceases to be the case as the stock of human capital increases and the marginal benefit of human capital investment falls. Moreover, it is important to notice that the just described behavior of human capital over the life cycle must take place, irrespective of the individual ability to accumulate human capital, i.e. $c^{j}($.$) . It is due solely to the fact that, while the benefit of human capital is time varying, the$ cost of human capital built up is not $3^{3}$

Now we can join our observations about the optimal retirement decision with those regarding the life cycle of human capital. By condition (7), we know that the age at which agent chooses to retire depends on her stock of human capital and so, eventually, on her ability to acquire human capital, i.e. on $c^{j}($.$) . The reason is simple: the higher the human capital, the higher the labor$ income, the smaller the incentive to retire and the later people retire from the labor force. But

\footnotetext{
${ }^{3}$ In principles it would be easy to speculate that also the cost of building up human capital is time varying and is, in particular, increasing as individuals age. If this feature were to be introduced here, it would strengthen our arguments.
} 
this is not enough to explain why we observe starkly different behavior regarding retirement in different economies. The crucial observation we make here gives a central role to the level of social security taxation $\tau$. In the empirical sections that follow we show that countries where the social security tax is high are also the ones where retirement takes place earlier and where the labor market, including the private sector, rewards relatively more seniority. We now try to rationalize these features through the framework we have proposed here.

If the SSS picks a high level of the social security tax, condition 10 shows that the marginal benefit of human capital accumulation falls. These has two effects: first, it decreases the overall level of human capital for any individual and at any age, i.e. $\forall j, i$; second, it increases the level of the Social Security benefit $b$ relatively to the wage, as condition (4) dictates, and so it builds an incentive for workers to retire earlier. But which individuals remain longer in the workforce? Once again, these are the most productive so that we would also observe that, as social security taxation increases, the marginal worker $j^{i}$ that is indifferent between working and retiring - defined by condition (8) - falls, labor market participation also falls but the average wage of active individuals increases. The increase is the average wage is not the result of a surge in productivity of senior workers, but rather the effect of selection pushed forward by the incidence of the social security tax. In economies where the social security $\operatorname{tax} \tau$ is higher, the private benefit of human capital accumulation falls, the Social Security benefit provided by SSS instead increases, but then only the most productive individuals find convenient to remain workers and postpone retirement. This selection is reflected in the average wage observed among senior workers and the labor market thus displays a more pronounced seniority premium that is though the consequence of the structure of the SSS, and not of a crucial function that senior workers provide in the economy. As a consequence of high social security taxation and the resulting low investment in human capital, the aggregate effective human capital $H$ is reduced, labor income stays stagnant and individuals face on average a strong incentive to retire earlier, whenever the SSS rules allows so. The selection taking place among workers as a consequence of the high level of the social 
security tax that some SSSs display is responsible for the fact that the average wage by age class among active workers increases with seniority. While the age profile of earnings is increasing for economies with high social security tax, a specular reasoning help us to conclude that SSSs with low social security tax do not present such a thorough selection among workers. Thus the average wage by age class first increases and then decreases in the second half of the working career. The age profile of earnings takes a more hump-shaped structure in these economies and the seniority premium falls.

The following proposition summarizes our discussion:

Proposition 2.1. Under the SSS defined above, we have:

1. the stock of human capital $h^{i}(j)$ first increases and then decreases over the life cycle, $\forall j$;

2. the aggregate level of human capital $H$ decreases as social security tax, $\tau$, increases;

3. the retirement age $r^{j}$ decreases as social security tax, $\tau$, increases, $\forall j$;

4. the ratio between average working income at the time of retirement and at entry in the labor market, i.e. the seniority premium, $\frac{\int_{0}^{1} w\left(h^{r^{j}}(j)\right) d j}{\int_{0}^{1} w\left(h^{i=1}(j)\right) d j}$, increases as social security tax, $\tau$, increases.

\section{$3 \quad$ Empirical Evidence}

\subsection{Differences in the Age Profile of Earnings Across European Coun- tries}

Policy makers might not realize that Social Security rules influence labor market features, so that the age profile of earnings accommodates to specific Social Security rules. Given that social security rules hardly vary within a country we are going to analyze differences across countries, 
and we do so using the European Community Household Panel (ECHP), a representative panel of the European workers.

Figure 1 shows the pattern of wage profiles in 14 European countries. Each line represents a different cohort, defined as individuals born in the same decade. These lines represent the average log wage across age, and are based on simple wage regressions shows in Table 6. In Italy, for example, wages of older workers grow over time as much as those of younger workers. In the United Kingdom this is not the case: wages for the 1940 cohort drop over time! In general, countries seem to differ quite extensively by how concave the age profile of earnings is.

Southern countries like Spain and Greece, and, as we just showed, Italy, show no evidence of bending of wages across age. These are typical countries where strong seniority systems seem to be in place. The wage-age profile is clearly different in the United Kingdom, Germany, the Netherlands, and Denmark, where not only wages at older ages decline across generations, even within cohorts the slope tends to get flatter.

Roughly speaking, European countries can, on the basis of their seniority premium, be divided into two groups. In the first group we find Austria, Belgium, Italy, and Spain where labor markets are relatively more rigid, less favorable to entry, and workers are more protected when employed. Such conditions lead to higher youth unemployment (ECHP 1994-2001), which creates downward pressure on wages of younger workers. This pressure diminishes as workers age, and with age we observe falling unemployment rates. Moreover, hourly wages in the private sector increase with seniority (2002 Labor Force Survey, Eurostat and ECHP, 1994-2001) even when workers' productivity is unlikely to do so.

Even though measuring productivity at the worker level is hard, no available evidence suggests that average productivity increases with age (see Roger and Wasmer 2009), certainly not after a certain age (see Skirbekk 2004 and Abowd and Kramartz, 1999), while the theoretical literature argues that productivity is hump-shaped during a worker's career ((Ben-Porath, 1967), (Kredler, 2008)). We are going to assume that, conditional on observable characteristics (including educa- 
tion, occupation, industry, and the like), there are no ex-ante systematic differences in the age profile of productivity of individual workers across developed European countries, other than because of differences in human capital investments. But productivity might still differ ex-post if more productive workers are less likely to retire that less productive ones.

If a country presents higher premia for seniority, there is a selection that would leaves only the most productive individuals active in the labor market at late ages. As first noticed by Lazear (1979) in a different context, if wages do not adjust efficiently to the shifting composition of the labor force, this creates an incentive for employers to push for Social Security rules that mandate early retirement.

In the second group of countries we find economies with more flexible labor markets like the UK, Germany and Sweden, wages appear to track individual productivity more closely. In these countries, salaries increase at the beginning of a workers' career, up to age 45-50, to fall later on as workers approach retirement. Unlike the previous case, in these economies unemployment rates for younger and older workers are similar, even across skill groups. Thus, with these labor markets firms have no particular incentive to prefer young workers to older ones. Workers tend to work longer, because wages and individual productivity are more aligned and Social Security benefits also tend to be less generous.

\subsection{The Relationship between the Age Profile of Earnings and Retire- ment Rules}

This section is going to shed some light on the relationship between the seniority system and several measures of Social Security generosity. Let us first define the specific feature of the labor market on which we will focus. Based on the wage-age profiles seen before we can rank countries based on the difference in the slope of wages between the 1980 cohort and the 1940 one. The higher that difference the more flexible the labor market. Table 1 shows that different slopes, 
that we derived in regressions outlined in the appendix. Table 2 instead, shows the difference in slopes. The negative of it is simply what we call the seniority premium. The closer to zero is the difference, the more similar are the changes in the hourly wage because of every additional year spent in the labor market between young and older workers, and thus the higher is the seniority premium.

The first evidence we provide is about what happens early in life, and how these decisions influence the age profile of earnings. The left panel of Figure 2 shows that in countries that have higher Social Security taxes workers invest much less in human capital, and the relationship seems strong and approximately linear. How this lower investment influences the earnings profiles is shown in the second panel. Countries where workers accumulate higher levels of human capital tend to have concave wage profiles, meaning that in these countries wages do not steadily increase with age $4^{4}$ In other words, where workers invest less in human capital these same workers seem to withdraw earlier from the labor market.

The next step is to define the generosity of the Social Security System. We'll proxy for the generosity using several different measures. Table 3 shows the first set of these measures, the ones based on the retirement age. The idea is simple, the lower the retirement age, the more generous the system. The upper-left panel in Figure 3 shows the correlation between the early retirement age as set by law and the seniority system. The correlation is negative but far from perfect. Most probably a better measure for the overall generosity is the average retirement age, as it also depends not only on the constraints set on ages but also on the overall generosity and on actuarial adjustments to the benefits when retirement is postponed. The second panel does indeed show a stronger correlation. As before, the higher the labor market flexibilities, the higher the retirement age. Using the median shows similar results and what works even better is the lowest quartile of retirement age, probably because it highlights that some countries (Italy more than others) allow very early exits from the labor market and have very strong seniority systems.

\footnotetext{
${ }^{4}$ The regression line shown in these figures are all weighted by the population of countries.
} 
Another way to measure generosity is by looking at replacement rates. Table 4 shows the different replacement rates. We computed them exploiting the panel as the benefits divided by the last wage. Figure 4 shows the corresponding correlations with the seniority premium. The larger the replacement rate the higher the seniority premia.

The negative correlation between retirement age and the seniority premium is a striking fact that turns out to be empirically robust to a series of control (educational classes, gender, and other demographics).

\section{Conclusions and Future Developments}

We highlighted the relationship in equilibrium between Social Security rules and the age profile of earnings. We showed that this relationship holds for European countries and developed a simple theoretical rationalization of this result. Social security rules and the implied social security tax provide strong incentives for the level and the pattern of accumulation of human capital over the life-cycle.

The main policy implication of this perspective is that Social Security reforms are closely linked to labor market reforms. This is, in our opinion, the main reason why countries have had such a hard time to reform their SSS: they often neglect the deep relationship between the labor market, specifically investments in human capital and the age profile of earnings, and retirement rules.

Let us complement the intuition set forth here with some additional features that are certainly relevant and that we intend to develop in the future. To fix ideas, think about economies with European-type labor markets: contracts are long term because employment protection legislation prevents employers from firing workers at will. The cross-country evidence we have produced shows that in countries where, on average, retirement takes place later, the difference between how much wages change in the first and the second half of workers' career is larger. This is the main prediction of the macroeconomic general equilibrium model we set up. 
In labor markets where the seniority premium is relatively large, both employers, and older and low skilled workers end up preferring a "loose" SSS: they pay higher social security taxes to support looser retirement requirements. This allocation is an equilibrium allocation that is only apparently paradoxical. In fact, when the age profile of earnings displays a large seniority premium, firms are happy to see older workers enter retirement. The reason is that, although the wage of these workers is likely to be higher, their productivity is unlikely to be so. Therefore employers would like instead to hire more productive younger workers who are likely to be paid below their productivity. Moreover, low skilled workers are also eager to exploit the looser retirement requirements and leave the labor force early, maybe taking advantage of the opportunities offered by the informal economy. The coalition between old and low skilled workers and employers makes a generous SSS politically sustainable, against the interest of the young generations that suffer high unemployment and, most importantly, contrary to the general interest of the economy.

In labor markets displaying low seniority premium instead, wages and productivity tend to be more aligned across different age groups, and for older workers in particular. Employers have low incentives to lobby for early retirement provisions and they shift their support towards stricter retirement requirements in exchange for lower social security contributions.

Notice the innovation of the mechanism we just described compared with Conde-Ruiz and Galasso (2003, 2004). In their papers, it is the fact that the median voter becomes relatively older to shift the equilibrium of the SSS. In our model it is the interaction between the age profile of earnings and Social Security rules, even if the median voter age does not change, to determine the equilibrium SSS of the economy. While both models coincide in predicting the support of low skilled workers for loose requirements for early retirement, in addition to them we could argue that employers too may favor "loose" SSSs when the age profile of earnings rewards relatively more seniority.

Unsurprisingly, a richer version of our argument also predicts that rigid labor markets severely reduce labor force participation for workers aged 55-65 or 50-69 (Gruber and Wise (1999, 2004)), 
an implication that finds strong empirical support. Interestingly enough, there are important cross-country variations in the way these "loose" systems are designed, with disability/sickness and unemployment benefits playing a more prominent role in some countries, and old-age benefits playing a more prominent role in others.

The rationalization provided by our model is not just a theoretical curiosity but it suggests how much society would gain by changing the retirement rules depends on the underlying age profile of earnings, i.e. on the labor market structure. Moreover, the shape of the age profile of earnings is a crucial determinant of how losses and gains due to the SSS are distributed across skill groups and generations.

After providing a rational for the observed cross-country relationship between SSSs and age profiles of earnings, we plan to extend our insights to study the puzzling high unemployment rate among high skilled young workers in Italy, Greece and Spain, the three countries displaying the largest seniority premium (see Figure 1). This is particularly interesting since economies without a seniority effect do not display this feature. But our extended perspective could rationalize this difference: if a generous SSS is associated with wage profiles that rewards relatively more seniority, less skilled elderly workers take advantage of the more flexible SSS requirements and retire. The more skilled elderly workers instead stay on the job longer: this asymmetry generates a relative abundance of skilled elder workers in the labor market. This relative abundance in turn delays the entry of young high skilled workers and is thus likely to be an important cause of the observed high unemployment rates in this skill group.

This observation is not only important for its redistributive implications but also for its discouraging effect on human capital accumulation in early periods of the life-cycle. This is one of the causes - one could argue - for staggering productivity growth and the relatively lower number of university graduates displayed in the set of countries with more generous retirement rules. In conclusion, this framework may also be fruitfully employed to analyze how low entry wages and low levels of education feed back into workers' fertility decisions. Low entry wages are likely to 
lower fertility and thus exacerbate the financial burden of the SSS. An age profile of earnings providing higher seniority premium, with the feature of low entry wages, also keeps young people financially dependent on their parents, thus reinforcing the status quo in these economies even further. 


\section{References}

John M. Abowd and Francis Kramarz. The analysis of labor markets using matched employer-employee data. In Handbook of Labor Economics, volume 3, pages 26292710. 1999. URL http://www.sciencedirect.com/science/article/B7P5V-4FJ8VR9-Y/2/ 1bda0b595a6235217e75fe65f55e0409.

Yoram Ben-Porath. The production of human capital and the life cycle of earnings. The Journal of Political Economy, 75(4):353-367, August 1967. URL http://www.jstor.org/stable/ 1828596.

Ignacio J. Conde-Ruiz, Vincenzo Galasso, and Paola Profeta. The evolution of retirement. CEPR Discussion Papers 4863, C.E.P.R. Discussion Papers, January 2005. URL http://ideas.repec . org/p/cpr/ceprdp/4863.html.

Ignazio J. Conde-Ruiz and Vincenzo Galasso. Early retirement. Review of Economic Dynamics, 6(1):12-36, January 2003. URL http://ideas.repec.org/a/red/issued/v6y2003i1p12-36. html.

Ignazio J. Conde-Ruiz and Vincenzo Galasso. The macroeconomics of early retirement. Journal of Public Economics, 88(9-10):1849-1869, August 2004. URL http://ideas.repec.org/a/eee/ pubeco/v88y2004i9-10p1849-1869.html.

Vincenzo Galasso. The Political Future of Social Security in Aging Societies. MIT Press Books, edition 1, volume 1, September 2008. ISBN 026257246x.

Johnathan Gruber and David A. Wise. Social Security and Retirement around the World. University of Chicago Press for NBER, Chicago, February 1999. ISBN 9780226310114.

Johnathan Gruber and David A. Wise. Social Security and Retirement around the World - MicroEstimation. University of Chicago Press for NBER, Chicago, March 2004. ISBN 9780226310183. 
Matthias Kredler. Experience vs obsolescence: A vintage-human-capital model. Universidad Carlos III Madrid, mimeo, 2008. URL http://papers.ssrn.com/sol3/papers.cfm?abstract_ $i d=1147244$.

Edward P. Lazear. Why is there mandatory retirement? Journal of Political Economy, 87(2): 1261-1284, December 1979. URL http://www.jstor.org/sici?sici=0033-5533(198405)99: 2\%3C275: IPALC $\% 3 E 2.0 . C 0 ; 2-X \& o r i g i n=r e p e c$.

OCSE. Pensions at a Glance 2011: Retirement-income Systems in OECD and G20 Countries. OECD Publishing, 2011. URL http://dx.doi.org/10.1787/pension_glance-2011-en.

Muriel Roger and Malgorzata Wasmer. Labour productivity differentiated by age and skills. Working paper, August 2009. URL http://www. eale.nl/Conference2009/PapersC/Wasmer. pdf.

Vegard Skirbekk. Age and individual productivity: A literature survey. in G. Feichtinger (ed.), Vienna Yearbook of Population Research, Austrian Academy of Sciences Press, 2004. ISBN 3-7001-3272-7.

SSA. Social Security Programs Throughout the World: Europe, 2010. Social Security Administration; Research, Statistics, \& Policy Analysis, 2010. URL http://www.ssa.gov/policy/docs/ progdesc/ssptw/.

Ignazio Visco. Ageing and pension system reform: Implications for financial markets and economic policies. Report, Report for the Deputies of the Group of Ten, September 2005. URL http: //www.imf.org/external/np/g10/2005/pdf/092005.pdf. 
Figure 1: Profile of the log Hourly Wage by Country and Cohort



Notes: Cohort classes group individuals born in the same decade (i.e. cohort 40 groups individuals born in the decade 1931-1940) 
Figure 2: Seniority Premium, Social Security Taxes, and Human Capital
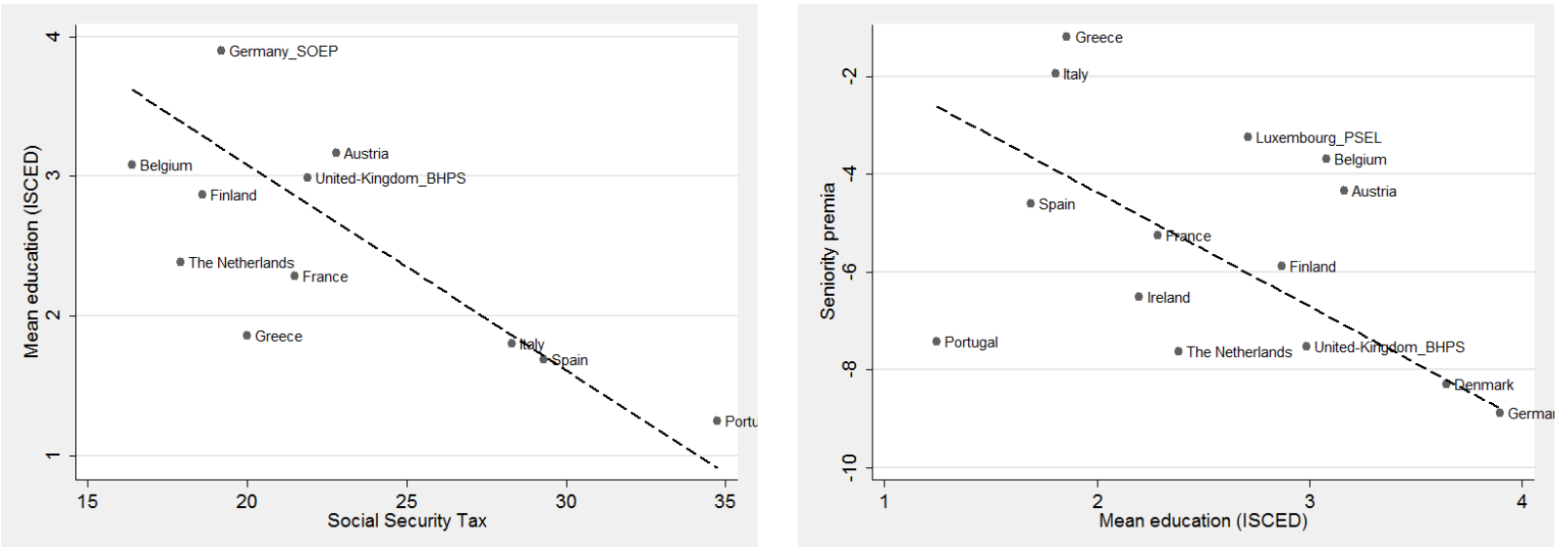

Notes: Human Capital is measured using the ISCED classifications. The Social Security taxes are taken from OCSE (2011) and SSA (2010). 
Figure 3: Seniority Premia Against Various Measures of Early Retirement Provisions


Notes: The UK and the Netherlands have no early retirement (here we are not accounting for disability retirement), old age requirements are reported in the place of early retirement requirements. 
Figure 4: Seniority Premium against Median RR - Panel Approach

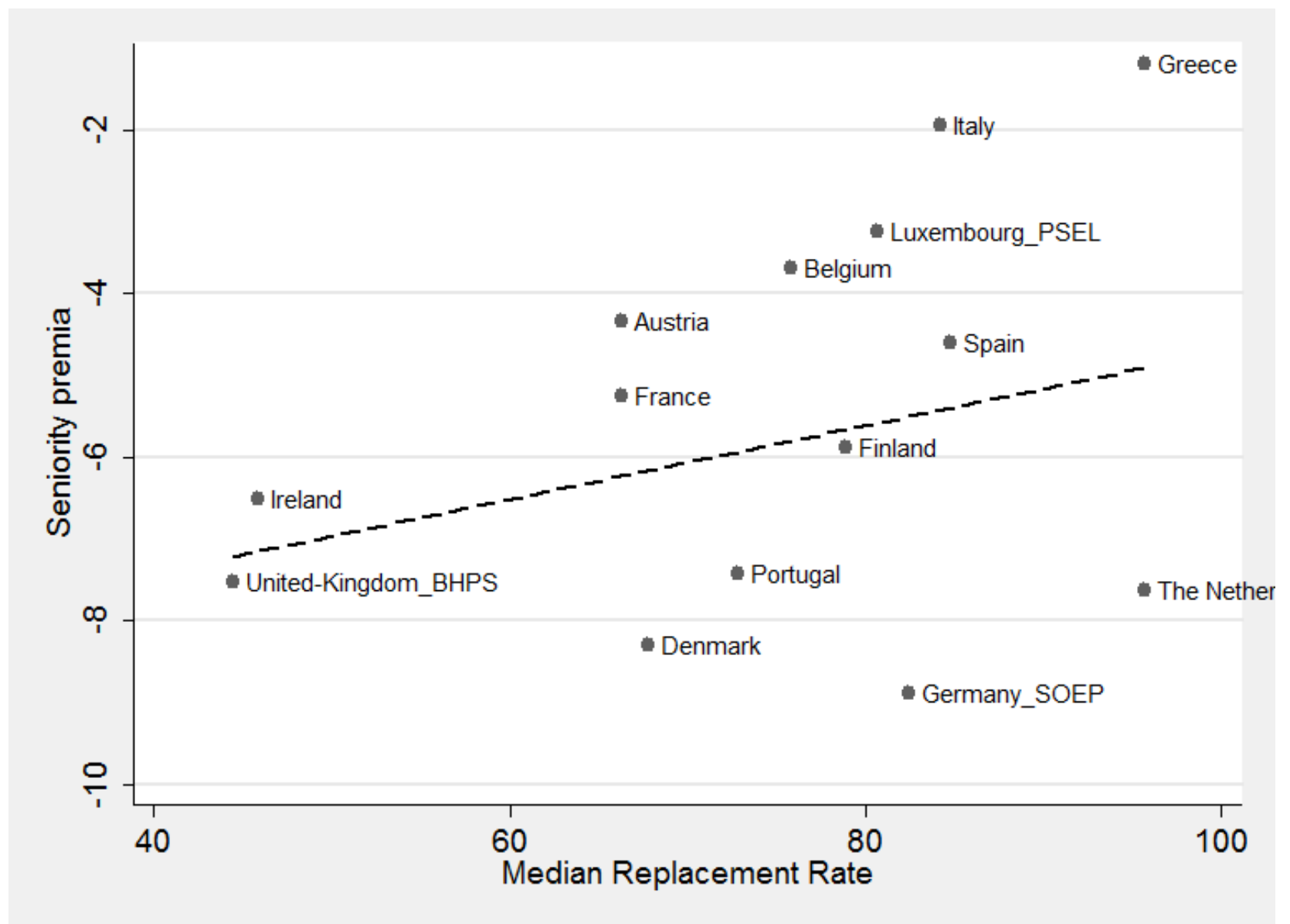

Notes: Based on ECHP data. 
Table 1: Slopes of log hourly wage profile (euro reported in 2005 prices), by country and cohort Men

\begin{tabular}{lcccccc}
\hline \hline & $\mathbf{1 9 4 0}$ & $\mathbf{1 9 5 0}$ & $\mathbf{1 9 6 0}$ & $\mathbf{1 9 7 0}$ & $\mathbf{1 9 8 0}$ & ISP Basic \\
\hline Denmark & 0.003 & 0.020 & 0.025 & 0.040 & 0.086 & 0.083 \\
The Netherlands & 0.003 & 0.023 & 0.026 & 0.047 & 0.079 & 0.076 \\
Belgium & 0.012 & 0.026 & 0.021 & 0.031 & 0.049 & 0.037 \\
France & 0.020 & 0.018 & 0.024 & 0.033 & 0.072 & 0.053 \\
Ireland & 0.035 & 0.039 & 0.043 & 0.063 & 0.100 & 0.065 \\
Italy & 0.033 & 0.025 & 0.031 & 0.045 & 0.052 & 0.020 \\
Greece & 0.058 & 0.044 & 0.066 & 0.075 & 0.070 & 0.012 \\
Spain & 0.027 & 0.026 & 0.046 & 0.053 & 0.073 & 0.046 \\
Portugal & -0.002 & 0.022 & 0.034 & 0.042 & 0.072 & 0.074 \\
Austria & -0.004 & 0.022 & 0.020 & 0.023 & 0.039 & 0.043 \\
Finland & -0.006 & 0.024 & 0.019 & 0.034 & 0.052 & 0.059 \\
Germany & 0.000 & 0.001 & 0.013 & 0.032 & 0.089 & 0.089 \\
Luxembourg & 0.056 & 0.036 & 0.024 & 0.047 & 0.089 & 0.033 \\
UK & -0.004 & 0.017 & 0.021 & 0.040 & 0.071 & 0.075 \\
\hline
\end{tabular}

Notes: Data ECHP for the period 1994-2001. For Germany, Luxembourg and the UK We use the ECHP surveys, the SOEP, PSELL and BHPS. The surveys of Austria and Luxembourg start from 1995, the one of Finland starts from 1996. Sweden is omitted as there are no data on monthly net wages. Slopes are derived from an OLS regression of the log hourly wages on the age and a constant. The Basic Inverse Seniority Premium (ISP Basic) is the difference between the slope of the log hourly wage profile for the cohort 1980 and the one for the cohort 1940 . 
Table 2: Inverse Seniority Premium - Men

\begin{tabular}{lcc}
\hline \hline Country & Basic Specification & Enriched Specification \\
\hline Denmark & 0.083 & 0.079 \\
The Netherlands & 0.076 & 0.079 \\
Belgium & 0.037 & 0.041 \\
France & 0.053 & 0.066 \\
Ireland & 0.065 & 0.070 \\
Italy & 0.020 & 0.022 \\
Greece & 0.012 & 0.033 \\
Spain & 0.046 & 0.042 \\
Portugal & 0.074 & 0.065 \\
Austria & 0.043 & 0.044 \\
Finland & 0.059 & 0.047 \\
Germany SOEP & 0.089 & 0.083 \\
Luxembourg PSEL & 0.033 & 0.054 \\
United-Kingdom BHPS & 0.075 & 0.074 \\
\hline \hline
\end{tabular}

Notes: In the Basic Specification the Inverse Seniority Premium is obtained as the difference between the coefficient of the variable "age" in the OLS regression of the log hourly wage on the age (and a constant) for the cohort 1980 and the one in the regression for the cohort 1940 (see Table 1). In the Enhanced Specification the Inverse Seniority Premium is the coefficient of the interaction term of the variable "age" and the dummy for "cohort 1980" in the OLS regression of the log hourly wage on the age and some other regressors, where the "cohort 1940" is the baseline (see Table 1bis). Regression controls for age, good health, disability, education, being someone that retires in the observed period (retiring), cohort and interaction between "age" and "retiring", interactions between "age" and "cohort". There is no info on disability in first wave (disab==0 for all) and no health information for Luxembourg. 
Table 3: Retirement age by country

\begin{tabular}{lcccccc}
\hline \hline & \multicolumn{2}{c}{ By law $^{a}$} & & \multicolumn{3}{c}{ From sample data $^{b}$} \\
\cline { 2 - 3 } \cline { 5 - 6 } COUNTRY & $\begin{array}{c}\text { Old } \\
\text { age }\end{array}$ & $\begin{array}{c}\text { Early } \\
\text { Retirement }\end{array}$ & & $\begin{array}{c}\text { Mean } \\
\text { Ret. Age }\end{array}$ & $\begin{array}{c}\text { Median } \\
\text { Ret. Age }\end{array}$ & $\begin{array}{c}\text { 25 Percentile } \\
\text { Ret. Age }\end{array}$ \\
\hline Denmark & 65 & 60 & & 60 & 62 & 60 \\
The Netherlands & 65 & $\cdots$ & & 64 & 65 & 62 \\
Belgium & 65 & 60 & & 60 & 61 & 57 \\
France & 60 & 56 & & 58 & 60 & 57 \\
Ireland & 66 & 55 & & 61 & 63 & 59 \\
Italy & 65 & 57 & & 58 & 59 & 55 \\
Greece & 65 & 60 & & 60 & 62 & 58 \\
Spain & 65 & 61 & & 62 & 64 & 61 \\
Portugal & 65 & 55 & & 60 & 63 & 56 \\
Austria & 65 & 61 & & 58 & 59 & 56 \\
Finland & 65 & 60 & & 58 & 60 & 57 \\
Germany SOEP & 65 & 59 & & 60 & 61 & 58 \\
Luxembourg PSEL & 65 & 57 & & 57 & 59 & 57 \\
United-Kingdom BHPS & 65 & $\ldots$ & & 60 & 63 & 58 \\
\hline$a)$ Source: Social Security Programs Through the World, http://www.ssa.gov/policy/docs/progdesc/ssptw/ \\
b) ECHP 1994-2001
\end{tabular}


Table 4: Replacement Rates (RR) - Men. My elaborations on ECHP.

\begin{tabular}{|c|c|c|}
\hline & Panel approach $^{a}$ & $\overline{\text { Cross-sectional Approach }}^{b}$ \\
\hline Denmark & $68 \%$ & $50 \%$ \\
\hline The Netherland & $96 \%$ & $78 \%$ \\
\hline Belgium & $76 \%$ & $63 \%$ \\
\hline France & $66 \%$ & $65 \%$ \\
\hline Ireland & $46 \%$ & $48 \%$ \\
\hline Italy & $84 \%$ & $73 \%$ \\
\hline Greece & $96 \%$ & $69 \%$ \\
\hline Spain & $85 \%$ & $65 \%$ \\
\hline Portugal & $73 \%$ & $87 \%$ \\
\hline Austria & $66 \%$ & $65 \%$ \\
\hline Finland & $79 \%$ & $26 \%$ \\
\hline Germany SOEP & $82 \%$ & $64 \%$ \\
\hline Luxembourg & $81 \%$ & $64 \%$ \\
\hline United-Kingdom & $44 \%$ & $44 \%$ \\
\hline $\begin{array}{l}\text { a) Median RR calculated } \\
\text { b) RR calculated as meat } \\
\text { individuals aged } 50-60\end{array}$ & $\begin{array}{l}\text { as first pension on last } \\
\text { pension for individuals } \\
\text { (cross-sectional approa }\end{array}$ & $\begin{array}{l}\text { vage (panel approach). } \\
\text { aged } 55-65 / \text { mean labor income for } \\
\text { ). }\end{array}$ \\
\hline
\end{tabular}

Table 5: Mean educational level (average Isced) - Men

\begin{tabular}{|c|c|c|}
\hline & \multicolumn{2}{|c|}{ Mean Isced } \\
\hline & All & $55+$ \\
\hline Denmark & 3.98 & 3.64 \\
\hline Netherlands & 2.56 & 2.38 \\
\hline Belgium & 3.78 & 3.08 \\
\hline France & 3.07 & 2.29 \\
\hline Ireland & 2.89 & 2.20 \\
\hline Italy & 2.55 & 1.80 \\
\hline Greece & 2.82 & 1.86 \\
\hline Spain & 2.60 & 1.69 \\
\hline Portugal & 1.62 & 1.24 \\
\hline Austria & 3.59 & 3.16 \\
\hline Finland & 3.69 & 2.87 \\
\hline Germany SOEP & 3.94 & 3.90 \\
\hline Luxembourg PSEL & 3.12 & 2.71 \\
\hline United-Kingdom BHPS & 3.82 & 2.98 \\
\hline
\end{tabular}


Our papers can be downloaded at:

http://cerp.unito.it/index.php/en/publications

\section{CeRP Working Paper Series}

\begin{tabular}{|c|c|}
\hline $\mathrm{N}^{\circ} 120 / 11$ & $\begin{array}{l}\text { Giovanni Mastrobuoni } \\
\text { Filippo Taddei }\end{array}$ \\
\hline$N^{\circ} 119 / 11$ & $\begin{array}{l}\text { Maarten van Rooij } \\
\text { Annamaria Lusardi } \\
\text { Rob Alessie }\end{array}$ \\
\hline$N^{\circ} 118 / 11$ & $\begin{array}{l}\text { Luca Beltrametti } \\
\text { Matteo Della Valle }\end{array}$ \\
\hline$N^{\circ} 117 / 11$ & $\begin{array}{l}\text { Riccardo Calcagno } \\
\text { Chiara Monticone }\end{array}$ \\
\hline $\mathrm{N}^{\circ} 116 / 11$ & $\begin{array}{l}\text { Annamaria Lusardi } \\
\text { Daniel Schneider } \\
\text { Peter Tufano }\end{array}$ \\
\hline$N^{\circ} 115 / 11$ & $\begin{array}{l}\text { Adele Atkinson } \\
\text { Flore-Anne Messy }\end{array}$ \\
\hline$N^{\circ} 114 / 11$ & $\begin{array}{l}\text { Leora Klapper } \\
\text { Georgios A. Panos }\end{array}$ \\
\hline$N^{\circ} 113 / 11$ & $\begin{array}{l}\text { Diana Crossan } \\
\text { David Feslier } \\
\text { Roger Hurnard }\end{array}$ \\
\hline $\mathrm{N}^{\circ} 112 / 11$ & $\begin{array}{l}\text { Johan Almenberg } \\
\text { Jenny Säve-Söderbergh }\end{array}$ \\
\hline $\mathrm{N}^{\circ} 111 / 11$ & $\begin{array}{l}\text { Elsa Fornero } \\
\text { Chiara Monticone }\end{array}$ \\
\hline$N^{\circ} 110 / 11$ & $\begin{array}{l}\text { Rob Alessie } \\
\text { Maarten Van Rooij } \\
\text { Annamaria Lusardi }\end{array}$ \\
\hline $\mathrm{N}^{\circ} 109 / 11$ & $\begin{array}{l}\text { Tabea Bucher-Koenen } \\
\text { Annamaria Lusardi }\end{array}$ \\
\hline $\mathrm{N}^{\circ} 108 / 11$ & Shizuka Sekita \\
\hline $\mathrm{N}^{\circ} 107 / 11$ & $\begin{array}{l}\text { Annamaria Lusardi } \\
\text { Olivia S. Mitchell }\end{array}$ \\
\hline $\mathrm{N}^{\circ} 106 / 11$ & $\begin{array}{l}\text { Annamaria Lusardi } \\
\text { Olivia S. Mitchell }\end{array}$ \\
\hline $\mathrm{N}^{\circ} 105 / 11$ & Agnese Romiti \\
\hline $\mathrm{N}^{\circ} 104 / 11$ & Ambrogio Rinaldi \\
\hline$N^{\circ} 103 / 10$ & $\begin{array}{l}\text { Fabio Bagliano } \\
\text { Claudio Morana }\end{array}$ \\
\hline$N^{\circ} 102 / 10$ & $\begin{array}{l}\text { Nuno Cassola } \\
\text { Claudio Morana }\end{array}$ \\
\hline $101 / 10$ & Tetyana Dubovyk \\
\hline
\end{tabular}

Age Before Beauty? Productivity and Work vs. Seniority and Early Retirement

Financial Literacy, Retirement Planning, and Household Wealth

Does the implicit pension debt mean anything after all?

Financial Literacy and the Demand for Financial Advice

Financially Fragile Households: Evidence and Implications

Assessing financial literacy in 12 countries: an OECD Pilot Exercise

Financial Literacy and Retirement Planning in View of a Growing Youth Demographic: The Russian Case

Financial Literacy and Retirement Planning in New Zealand

Financial Literacy and Retirement Planning in Sweden

Financial Literacy and Pension Plan Participation in Italy

Financial Literacy, Retirement Preparation and Pension

Expectations in the Netherlands

Financial Literacy and Retirement Planning in Germany

Financial Literacy and Retirement Planning in Japan

Financial Literacy and Retirement Planning in the United States

Financial Literacy Around the World: An Overview

Immigrants-natives complementarities in production: evidence from Italy

Pension awareness and nation-wide auto-enrolment: the Italian experience

The Great Recession: US dynamics and spillovers to the world economy

The 2007-? financial crisis: a money market perspective

Macroeconomic Aspects of Italian Pension Reforms of 1990s 


\begin{tabular}{|c|c|}
\hline $\mathrm{N}^{\circ} 100 / 10$ & $\begin{array}{l}\text { Laura Piatti } \\
\text { Giuseppe Rocco }\end{array}$ \\
\hline $\mathrm{N}^{\circ} 99 / 10$ & $\begin{array}{l}\text { Fabio Bagliano } \\
\text { Claudio Morana }\end{array}$ \\
\hline $\mathrm{N}^{\circ} 98 / 10$ & $\begin{array}{l}\text { Annamaria Lusardi } \\
\text { Daniel Schneider } \\
\text { Peter Tufano }\end{array}$ \\
\hline $\mathrm{N}^{\circ} 97 / 10$ & $\begin{array}{l}\text { Carlo Maccheroni } \\
\text { Tiziana Barugola }\end{array}$ \\
\hline $\mathrm{N}^{\circ} 96 / 10$ & $\begin{array}{l}\text { Riccardo Calcagno } \\
\text { Mariacristina Rossi }\end{array}$ \\
\hline$N^{\circ} 95 / 10$ & $\begin{array}{l}\text { Flavia Coda Moscarola } \\
\text { Elsa Fornero } \\
\text { Mariacristina Rossi }\end{array}$ \\
\hline $\mathrm{N}^{\circ} 94 / 10$ & $\begin{array}{l}\text { John A. List } \\
\text { Sally Sadoff } \\
\text { Mathis Wagner }\end{array}$ \\
\hline $\mathrm{N}^{\circ} 93 / 10$ & Mathis Wagner \\
\hline$N^{\circ} 92 / 10$ & $\begin{array}{l}\text { Rob Alessie } \\
\text { Michele Belloni }\end{array}$ \\
\hline $\mathrm{N}^{\circ} 91 / 09$ & $\begin{array}{l}\text { Annamaria Lusardi } \\
\text { Olivia S. Mitchell } \\
\text { Vilsa Curto }\end{array}$ \\
\hline $\mathrm{N}^{\circ} 90 / 09$ & $\begin{array}{l}\text { Annamaria Lusardi } \\
\text { Olivia S. Mitchell }\end{array}$ \\
\hline$N^{\circ} 89 / 09$ & Elena Vigna \\
\hline $\mathrm{N}^{\circ} 88 / 09$ & Maela Giofré \\
\hline $\mathrm{N}^{\circ} 87 / 09$ & $\begin{array}{l}\text { Elsa Fornero } \\
\text { Annamaria Lusardi } \\
\text { Chiara Monticone }\end{array}$ \\
\hline$N^{\circ} 86 / 09$ & $\begin{array}{l}\text { Margherita Borella } \\
\text { Flavia Coda Moscarola }\end{array}$ \\
\hline$N^{\circ} 85 / 09$ & $\begin{array}{l}\text { Cathal O'Donoghue } \\
\text { John Lennon } \\
\text { Stephen Hynes } \\
\text { Luca Spataro }\end{array}$ \\
\hline $\mathrm{N}^{\circ} 83 / 09$ & $\begin{array}{l}\text { Annamaria Lusardi } \\
\text { Peter Tufano }\end{array}$ \\
\hline$N^{\circ} 82 / 09$ & $\begin{array}{l}\text { Carolina Fugazza } \\
\text { Massimo Guidolin } \\
\text { Giovanna Nicodano }\end{array}$ \\
\hline$N^{\circ} 81 / 09$ & $\begin{array}{l}\text { Fabio Bagliano } \\
\text { Claudio Morana }\end{array}$ \\
\hline
\end{tabular}

L'educazione e la comunicazione previdenziale - Il caso italiano

The effects of US economic and financial crises on euro area convergence

The Economic Crisis and Medical Care Usage

E se l'aspettativa di vita continuasse la sua crescita? Alcune ipotesi per le generazioni italiane 1950-2005

Portfolio Choice and Precautionary Savings

Parents/children “deals": Inter-Vivos Transfers and Living Proximity

So you want to run an experiment, now what? Some Simple Rules of Thumb for Optimal Experimental Design

The Heterogeneous Labor Market Effects of Immigration

Retirement choices in Italy: what an option value model tells us

Financial Literacy among the Young:

Evidence and Implications for Consumer Policy

How Ordinary Consumers Make Complex Economic Decisions: Financial Literacy and Retirement Readiness

Mean-variance inefficiency of CRRA and CARA utility functions for portfolio selection in defined contribution pension schemes

Convergence of EMU Equity Portfolios

Adequacy of Saving for Old Age in Europe

Microsimulation of Pension Reforms: Behavioural versus Nonbehavioural Approach

The Life-Cycle Income Analysis Model (LIAM): A Study of a Flexible Dynamic Microsimulation Modelling Computing Framework

Il sistema previdenziale italiano dallo shock petrolifero del 1973 al Trattato di Maastricht del 1993

Debt Literacy, Financial Experiences, and Overindebtedness

Time and Risk Diversification in Real Estate Investments: Assessing the Ex Post Economic Value

Permanent and Transitory Dynamics in House Prices and Consumption: Cross-Country Evidence 


\begin{tabular}{|c|c|}
\hline $\mathrm{N}^{\circ} 80 / 08$ & Claudio Campanale \\
\hline $\mathrm{N}^{\circ} 79 / 08$ & Annamaria Lusardi \\
\hline $\mathrm{N}^{\circ} 78 / 08$ & $\begin{array}{l}\text { Margherita Borella } \\
\text { Giovanna Segre }\end{array}$ \\
\hline $\mathrm{N}^{\circ} 77 / 08$ & $\begin{array}{l}\text { Giovanni Guazzarotti } \\
\text { Pietro Tommasino }\end{array}$ \\
\hline $\mathrm{N}^{\circ} 76 / 08$ & $\begin{array}{l}\text { Riccardo Calcagno } \\
\text { Elsa Fornero } \\
\text { Mariacristina Rossi }\end{array}$ \\
\hline $\mathrm{N}^{\circ} 75 / 08$ & $\begin{array}{l}\text { Harold Alderman } \\
\text { Johannes Hoogeveen } \\
\text { Mariacristina Rossi }\end{array}$ \\
\hline $\mathrm{N}^{\circ} 74 / 08$ & Maela Giofré \\
\hline $\mathrm{N}^{\circ} 73 / 08$ & $\begin{array}{l}\text { Michele Belloni } \\
\text { Rob Alessie }\end{array}$ \\
\hline $\mathrm{N}^{\circ} 72 / 08$ & $\begin{array}{l}\text { Annamaria Lusardi } \\
\text { Olivia Mitchell }\end{array}$ \\
\hline $\mathrm{N}^{\circ} 71 / 07$ & Flavia Coda Moscarola \\
\hline
\end{tabular}

$\begin{array}{ll}\mathrm{N}^{\circ} 70 / 07 & \text { Radha Iyengar } \\ & \text { Giovanni Mastrobuoni }\end{array}$

N ${ }^{\circ}$ 69/07 Carolina Fugazza

Massimo Guidolin

Giovanna Nicodano

$\mathrm{N}^{\circ}$ 68/07 Massimo Guidolin

Giovanna Nicodano

$N^{\circ} 67 / 07 \quad$ Carolina Fugazza

Maela Giofré

Giovanna Nicodano

$N^{\circ}$ 66/07 Maarten van Rooij

Annamaria Lusardi

Rob Alessie

$\mathrm{N}^{\circ} 65 / 07 \quad$ Annamaria Lusardi

$\begin{array}{ll}\mathrm{N}^{\circ} 64 / 07 & \begin{array}{l}\text { Carlo Casarosa } \\ \text { Luca Spataro }\end{array} \\ \mathrm{N}^{\circ} 63 / 07 & \text { Claudio Campanale } \\ \mathrm{N}^{\circ} 62 / 07 & \begin{array}{l}\text { Margherita Borella } \\ \text { Elsa Fornero } \\ \text { Mariacristina Rossi }\end{array}\end{array}$

Learning, Ambiguity and Life-Cycle Portfolio Allocation

Increasing the Effectiveness of Financial Education in the Workplace

Le pensioni dei lavoratori parasubordinati: prospettive dopo un decennio di gestione separata

The Annuity Market in an Evolving Pension System: Lessons from Italy

The Effect of House Prices on Household Saving: The Case of Italy

Preschool Nutrition and Subsequent Schooling Attainment: Longitudinal Evidence from Tanzania

Information Asymmetries and Foreign Equity Portfolios: Households versus Financial Investors

The Importance of Financial Incentives on Retirement Choices: New Evidence for Italy

Planning and Financial Literacy: How Do Women Fare?

Women participation and caring decisions: do different institutional frameworks matter? A comparison between Italy and The Netherlands

The Political Economy of the Disability Insurance. Theory and Evidence of Gubernatorial Learning from Social Security Administration Monitoring

Investing in Mixed Asset Portfolios: the Ex-Post Performance

Small Caps in International Diversified Portfolios

International Diversification and Labor Income Risk

Financial Literacy and Stock Market Participation

Household Saving Behavior: The Role of Literacy, Information and Financial Education Programs

(Updated version June 08: "Financial Literacy: An Essential Tool for Informed Consumer Choice?")

Rate of Growth of Population, Saving and Wealth in the Basic Life-cycle Model when the Household is the Decision Unit

Life-Cycle Portfolio Choice: The Role of Heterogeneous UnderDiversification

Does Consumption Respond to Predicted Increases in Cash-onhand Availability? Evidence from the Italian "Severance Pay" 


\begin{tabular}{|c|c|}
\hline $\mathrm{N}^{\circ} 61 / 07$ & Irina Kovrova \\
\hline $\mathrm{N}^{\circ} 60 / 07$ & $\begin{array}{l}\text { Riccardo Cesari } \\
\text { Giuseppe Grande } \\
\text { Fabio Panetta }\end{array}$ \\
\hline $\mathrm{N}^{\circ} 59 / 07$ & $\begin{array}{l}\text { Riccardo Calcagno } \\
\text { Roman Kraeussl } \\
\text { Chiara Monticone }\end{array}$ \\
\hline $\mathrm{N}^{\circ} 58 / 07$ & $\begin{array}{l}\text { Elisa Luciano } \\
\text { Jaap Spreeuw } \\
\text { Elena Vigna }\end{array}$ \\
\hline $\mathrm{N}^{\circ} 57 / 07$ & $\begin{array}{l}\text { Giovanni Mastrobuoni } \\
\text { Matthew Weinberg }\end{array}$ \\
\hline $\mathrm{N}^{\circ} 56 / 07$ & $\begin{array}{l}\text { John A. Turner } \\
\text { Satyendra Verma }\end{array}$ \\
\hline $\mathrm{N}^{\circ} 55 / 06$ & Antonio Abatemarco \\
\hline $\mathrm{N}^{\circ} 54 / 06$ & $\begin{array}{l}\text { Annamaria Lusardi } \\
\text { Olivia S. Mitchell }\end{array}$ \\
\hline $\mathrm{N}^{\circ} 53 / 06$ & Giovanni Mastrobuoni \\
\hline $\mathrm{N}^{\circ} 52 / 06$ & $\begin{array}{l}\text { Luigi Guiso } \\
\text { Tullio Jappelli }\end{array}$ \\
\hline $\mathrm{N}^{\circ} 51 / 06$ & Giovanni Mastrobuoni \\
\hline $\mathrm{N}^{\circ} 50 / 06$ & $\begin{array}{l}\text { Andrea Buffa } \\
\text { Chiara Monticone }\end{array}$ \\
\hline$N^{\circ} 49 / 06$ & Mariacristina Rossi \\
\hline $\mathrm{N}^{\circ} 48 / 06$ & $\begin{array}{l}\text { Onorato Castellino } \\
\text { Elsa Fornero }\end{array}$ \\
\hline $\mathrm{N}^{\circ} 47 / 06$ & $\begin{array}{l}\text { Michele Belloni } \\
\text { Carlo Maccheroni }\end{array}$ \\
\hline $\mathrm{N}^{\circ} 46 / 05$ & $\begin{array}{l}\text { Annamaria Lusardi } \\
\text { Olivia S. Mitchell }\end{array}$ \\
\hline $\mathrm{N}^{\circ} 45 / 05$ & Claudio Campanale \\
\hline $\mathrm{N}^{\circ} 44 / 05$ & Henrik Cronqvist \\
\hline $\mathrm{N}^{\circ} 42 / 05$ & $\begin{array}{l}\text { John Beshears } \\
\text { James J. Choi } \\
\text { David Laibson } \\
\text { Brigitte C. Madrian } \\
\text { Margherita Borella } \\
\text { Flavia Coda Moscarola }\end{array}$ \\
\hline $\mathrm{N}^{\circ} 41 / 05$ & $\begin{array}{l}\text { Massimo Guidolin } \\
\text { Giovanna Nicodano }\end{array}$ \\
\hline$N^{\circ} 40 / 05$ & $\begin{array}{l}\text { Carolina Fugazza } \\
\text { Massimo Guidolin } \\
\text { Giovanna Nicodano }\end{array}$ \\
\hline
\end{tabular}

Effects of the Introduction of a Funded Pillar on the Russian Household Savings: Evidence from the 2002 Pension Reform

La Previdenza Complementare in Italia:

Caratteristiche, Sviluppo e Opportunità per i Lavoratori

An Analysis of the Effects of the Severance Pay Reform on Credit to Italian SMEs

Modelling Stochastic Mortality for Dependent Lives

Heterogeneity in Intra-Monthly Consumption. Patterns, SelfControl, and Savings at Retirement

Why Some Workers Don't Take 401(k) Plan Offers: Inertia versus Economics

On the Measurement of Intra-Generational Lifetime Redistribution in Pension Systems

Baby Boomer Retirement Security: The Roles of Planning, Financial Literacy, and Housing Wealth

Labor Supply Effects of the Recent Social Security Benefit Cuts: Empirical Estimates Using Cohort Discontinuities

Information Acquisition and Portfolio Performance

The Social Security Earnings Test Removal. Money Saved or Money Spent by the Trust Fund?

Do European Pension Reforms Improve the Adequacy of Saving?

Examining the Interaction between Saving and Contributions to Personal Pension Plans. Evidence from the BHPS

Public Policy and the Transition to Private Pension Provision in the United States and Europe

Actuarial Neutrality when Longevity Increases: An Application to the Italian Pension System

Financial Literacy and Planning: Implications for Retirement Wellbeing

Increasing Returns to Savings and Wealth Inequality

Advertising and Portfolio Choice

The Importance of Default Options for Retirement Saving Outcomes: Evidence from the United States

Distributive Properties of Pensions Systems: a Simulation of the Italian Transition from Defined Benefit to Defined Contribution Small Caps in International Equity Portfolios: The Effects of Variance Risk.

Investing for the Long-Run in European Real Estate. Does Predictability Matter? 


\begin{tabular}{|c|c|}
\hline $\mathrm{N}^{\circ} 39 / 05$ & Anna Rita Bacinello \\
\hline $\mathrm{N}^{\circ} 38 / 05$ & $\begin{array}{l}\text { Carolina Fugazza } \\
\text { Federica Teppa }\end{array}$ \\
\hline$N^{\circ} 37 / 04$ & Jay Ginn \\
\hline $\mathrm{N}^{\circ} 36 / 04$ & Laurence J. Kotlikoff \\
\hline$N^{\circ} 35 / 04$ & $\begin{array}{l}\text { Monika Bütler } \\
\text { Olivia Huguenin } \\
\text { Federica Teppa }\end{array}$ \\
\hline $\mathrm{N}^{\circ} 34 / 04$ & Chourouk Houssi \\
\hline$N^{\circ} 33 / 04$ & $\begin{array}{l}\text { Elsa Fornero } \\
\text { Carolina Fugazza } \\
\text { Giacomo Ponzetto }\end{array}$ \\
\hline $\mathrm{N}^{\circ} 32 / 04$ & $\begin{array}{l}\text { Angelo Marano } \\
\text { Paolo Sestito }\end{array}$ \\
\hline $\mathrm{N}^{\circ} 31 / 03$ & Giacomo Ponzetto \\
\hline $\mathrm{N}^{\circ} 30 / 03$ & $\begin{array}{l}\text { Bas Arts } \\
\text { Elena Vigna }\end{array}$ \\
\hline$N^{\circ} 29 / 02$ & Marco Taboga \\
\hline $\mathrm{N}^{\circ} 28 / 02$ & Luca Spataro \\
\hline $\mathrm{N}^{\circ} 27 / 02$ & Reinhold Schnabel \\
\hline $\mathrm{N}^{\circ} 26 / 02$ & E. Philip Davis \\
\hline $\mathrm{N}^{\circ} 25 / 02$ & $\begin{array}{l}\text { Edmund Cannon } \\
\text { Ian Tonks }\end{array}$ \\
\hline $\mathrm{N}^{\circ} 24 / 02$ & $\begin{array}{l}\text { Laura Ballotta } \\
\text { Steven Haberman }\end{array}$ \\
\hline $\mathrm{N}^{\circ} 23 / 02$ & Ermanno Pitacco \\
\hline $\mathrm{N}^{\circ} 22 / 02$ & $\begin{array}{l}\text { Chris Soares } \\
\text { Mark Warshawsky }\end{array}$ \\
\hline $\mathrm{N}^{\circ} 21 / 02$ & $\begin{array}{l}\text { Olivia S. Mitchell } \\
\text { David McCarthy }\end{array}$ \\
\hline$N^{\circ} 20 / 02$ & Mauro Mastrogiacomo \\
\hline $\mathrm{N}^{\circ} 19 / 02$ & $\begin{array}{l}\text { Paolo Battocchio } \\
\text { Francesco Menoncin }\end{array}$ \\
\hline $\mathrm{N}^{\circ} 18 / 02$ & Francesco Daveri \\
\hline $\mathrm{N}^{\circ} 17 / 02$ & $\begin{array}{l}\text { Richard Disney and } \\
\text { Sarah Smith }\end{array}$ \\
\hline
\end{tabular}

Modelling the Surrender Conditions in Equity-Linked Life Insurance

An Empirical Assessment of the Italian Severance Payment (TFR)

Actuarial Fairness or Social Justice?

A Gender Perspective on Redistribution in Pension Systems

Pensions Systems and the Intergenerational Distribution of Resources

What Triggers Early Retirement. Results from Swiss Pension Funds

Le Vieillissement Démographique :

Problématique des Régimes de Pension en Tunisie

A Comparative Analysis of the Costs of Italian Individual Pension Plans

Older Workers and Pensioners: the Challenge of Ageing on the Italian Public Pension System and Labour Market

Risk Aversion and the Utility of Annuities

A Switch Criterion for Defined Contribution Pension Schemes

The Realized Equity Premium has been Higher than Expected: Further Evidence

New Tools in Micromodeling Retirement Decisions: Overview and Applications to the Italian Case

Annuities in Germany before and after the Pension Reform of 2001

Issues in the Regulation of Annuities Markets

The Behaviour of UK Annuity Prices from 1972 to the Present

Valuation of Guaranteed Annuity Conversion Options

Longevity Risk in Living Benefits

Annuity Risk: Volatility and Inflation Exposure in Payments from Immediate Life Annuities

Annuities for an Ageing World

Dual Retirement in Italy and Expectations

Optimal Portfolio Strategies with Stochastic Wage Income and Inflation: The Case of a Defined Contribution Pension Plan

Labor Taxes and Unemployment: a Survey of the Aggregate Evidence

The Labour Supply Effect of the Abolition of the Earnings Rule for Older Workers in the United Kingdom 


\begin{tabular}{|c|c|c|}
\hline $\mathrm{N}^{\circ} 16 / 01$ & $\begin{array}{l}\text { Estelle James and } \\
\text { Xue Song }\end{array}$ & $\begin{array}{l}\text { Annuities Markets Around the World: Money's Worth and Risk } \\
\text { Intermediation }\end{array}$ \\
\hline $\mathrm{N}^{\circ} 15 / 01$ & Estelle James & $\begin{array}{l}\text { How Can China Solve ist Old Age Security Problem? The } \\
\text { Interaction Between Pension, SOE and Financial Market Reform }\end{array}$ \\
\hline $\mathrm{N}^{\circ} 14 / 01$ & Thomas H. Noe & Investor Activism and Financial Market Structure \\
\hline $\mathrm{N}^{\circ} 13 / 01$ & Michela Scatigna & Institutional Investors, Corporate Governance and Pension Funds \\
\hline $\mathrm{N}^{\circ} 12 / 01$ & Roberta Romano & $\begin{array}{l}\text { Less is More: Making Shareholder Activism a Valuable } \\
\text { Mechanism of Corporate Governance }\end{array}$ \\
\hline $\mathrm{N}^{\circ} 11 / 01$ & $\begin{array}{l}\text { Mara Faccio and Ameziane } \\
\text { Lasfer }\end{array}$ & $\begin{array}{l}\text { Institutional Shareholders and Corporate Governance: The Case } \\
\text { of UK Pension Funds }\end{array}$ \\
\hline $\mathrm{N}^{\circ} 10 / 01$ & $\begin{array}{l}\text { Vincenzo Andrietti and Vincent } \\
\text { Hildebrand }\end{array}$ & $\begin{array}{l}\text { Pension Portability and Labour Mobility in the United States. } \\
\text { New Evidence from the SIPP Data }\end{array}$ \\
\hline $\mathrm{N}^{\circ} 9 / 01$ & Hans Blommestein & $\begin{array}{l}\text { Ageing, Pension Reform, and Financial Market Implications in } \\
\text { the OECD Area }\end{array}$ \\
\hline $\mathrm{N}^{\circ} 8 / 01$ & Margherita Borella & $\begin{array}{l}\text { Social Security Systems and the Distribution of Income: an } \\
\text { Application to the Italian Case }\end{array}$ \\
\hline$N^{\circ} 7 / 01$ & Margherita Borella & $\begin{array}{l}\text { The Error Structure of Earnings: an Analysis on Italian } \\
\text { Longitudinal Data }\end{array}$ \\
\hline$N^{\circ} 6 / 01$ & Flavia Coda Moscarola & $\begin{array}{l}\text { The Effects of Immigration Inflows on the Sustainability of the } \\
\text { Italian Welfare State }\end{array}$ \\
\hline $\mathrm{N}^{\circ} 5 / 01$ & Vincenzo Andrietti & $\begin{array}{l}\text { Occupational Pensions and Interfirm Job Mobility in the } \\
\text { European Union. Evidence from the ECHP Survey }\end{array}$ \\
\hline $\mathrm{N}^{\circ} 4 / 01$ & Peter Diamond & Towards an Optimal Social Security Design \\
\hline $\mathrm{N}^{\circ} 3 / 00$ & $\begin{array}{l}\text { Emanuele Baldacci } \\
\text { Luca Inglese }\end{array}$ & $\begin{array}{l}\text { Le caratteristiche socio economiche dei pensionati in Italia. } \\
\text { Analisi della distribuzione dei redditi da pensione (only available } \\
\text { in the Italian version) }\end{array}$ \\
\hline $\mathrm{N}^{\circ} 2 / 00$ & $\begin{array}{l}\text { Pier Marco Ferraresi } \\
\text { Elsa Fornero }\end{array}$ & $\begin{array}{l}\text { Social Security Transition in Italy: Costs, Distorsions and (some) } \\
\text { Possible Correction }\end{array}$ \\
\hline $\mathrm{N}^{\circ} 1 / 00$ & Guido Menzio & Opting Out of Social Security over the Life Cycle \\
\hline
\end{tabular}

